\title{
Successful treatment of confluent and reticulated papillomatosis with tetracycline and mupirocin
}

\begin{abstract}
Confluent and reticulated papillomatosis characterized by hyperkeratotic-pigmented papules is a rare dermatosis, which tends to settle in seborrheic areas. Some cutaneous disorders share the same features. Herein, we report a 51-year-old man with confluent and reticulated papillomatosis who was followed up as tinea versicolor which was unresponsive to treatment for six months. Confluent and reticulated papillomatosis should be kept in mind in patients with localized reticular pigmentation involving the upper trunk and neck.

Keywords: Confluent and reticulated papillomatosis, tinea versicolor, tetracycline, mupirocin

Öz

Hiperkeratotik pigmentli papüller ile karakterize konfluent ve retiküle papillomatozis, seboreik bölgelerde yerleşme eğiliminde olan nadir bir hastalıktır. Bazı deri hastalıkları onunla bazı klinik özelliklerini paylaşır. Bu yazıda, altı aylık tedaviye yanıtsız tinea versikolor olarak takip edilen konfluent retiküle papillomatozisli 51 yaşında bir erkek hasta sunuldu. Konfluent ve retiküle papillomatozis vücudun üst kısmında ve boyunda lokalize retiküler pigmentasyon olan hastalarda akılda tutulmalıdır.

Anahtar Kelimeler: Konfluent retiküle papillomatozis, tinea versikolor, tetrasiklin, mupirosin
\end{abstract}

\section{Introduction}

Confluent and reticulated papillomatosis (CRP) characterized by aberrant keratinization and hyperkeratotic-pigmented papules and peripheral reticulation involving seborrheic areas is a rare dermatosis. Consensus on the etiology and triggers of the disease has not been provided yet. Histopathological findings are nonspecific, and it can be diagnosed according to the clinical findings. Thus, some cutaneous disorders can share some features of CRP, and some patients may be exposed to ineffective and unnecessary treatment ${ }^{1}$. Herein, we present the case of a patient with CRP followed up erroneously as tinea versicolor for about six months and treated successfully with tetracycline and mupirocin.

\section{Case Report}

A 51-year-old male patient presented with the complaint of rash in the neck region, over a period of six-months. Physical examination revealed reticulated, hyperpigmented, and slightly scaly plaques in the neck region (Figure 1). His medical history revealed frequent use of topical and oral antifungal agents for the treatment of tinea versicolor. Potassium hydroxide preparation of the skin lesion was negative. Histopathological examination of the punch biopsy specimens revealed papillomatosis and acanthosis in the epidermis with mild hyperkeratosis in the stratum corneum, a slightly thickened stratum granulosum, and melanosis in the basal layer (Figure 2). The patient's complaints resolved completely with oral tetracycline 500 mg twice a day and

Address for Correspondence/Yazışma Adresi: Hatice Ataş MD, Dışkapı Yıldırım Beyazıt Training and Research Hospital, Dermatology, Ankara Phone: +903125962000 E-mail: drhaticeartik@gmail.com Received/Geliș Tarihi: 09.01.2017 Accepted/Kabul Tarihi: 07.12.2017 ORCID ID: orcid.org/0000-0003-3074-5989 
topical mupirocin once a day at the end of two weeks of treatment (Figure 1).

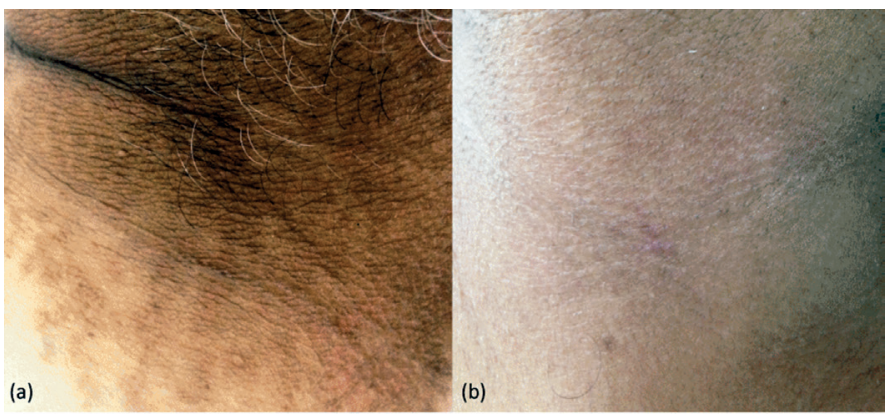

Figure 1. a) Images of skin lesion before and b) after treatment

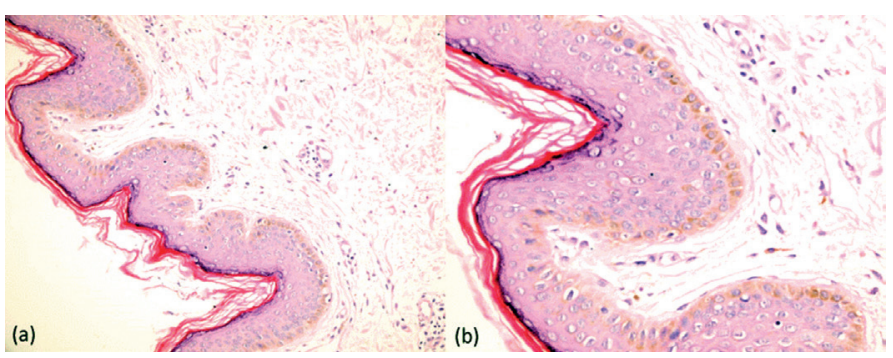

Figure 2. a) Papillomatosis and acanthosis in epidermis with mild hyperkeratosis in stratum corneum, a slightly thickened stratum granulosum, melanosis in the basal layer (hematoxylin and eosin $x 200$ ). b) Melanosis in the basal layer of epidermis with papillomatosis (hematoxylin and eosin $x 400$ )

\section{Discussion}

Disordered keratinization, altered keratinocyte differentiation and brown hyperpigmentation due to increased melanosomes in the epidermis are some histopathological features of CRP. It is a white and male predominant disease. Age of onset of CRP ranges between 3 and 55-year ${ }^{1}$. Cases from Turkey are summarized in Table 1. Our patient was a 51-year-old male patient, and consistent with common features of CRP such as age, race, localization and general aspects of the lesions. Seborrheic areas such as the nape, axillae, upper chest and back, forehead and the pubic region are the typical involvement areas of the $\mathrm{CRP}^{1}$. In our case, the involvement area was the neck region and the clinical features such as reticulated, hyperpigmented, and slightly scaly plaques were compatible with that of CRP.

Insulin resistance, keratinization disorders, developing an abnormal host response against bacterial or fungal agents, such as Dietzia papillomatosis (type strain N 1280T) and Malassezia furfur, amyloid deposition, and a loss-of-function mutation in keratin 16 and genetic disorders have been suggested for the etiology and pathogenesis. Melanogenesis and transient epidermal hyperplasia can be induced by ultraviolet radiation. It may be also a variant of cutaneous amyloidosis ${ }^{1-3}$. Malassezia colonization can be detected, and improved with antifungal treatment. However, there are many CRP cases of undetected Malassezia or unresponsive to antifungal therapy ${ }^{4}$. We did not find any etiology related to CRP. There was no evidence of fungal infection detected by potassium hydroxide and Wood's lamp examinations. In addition, we could not get response to antifungal therapy. CRP was

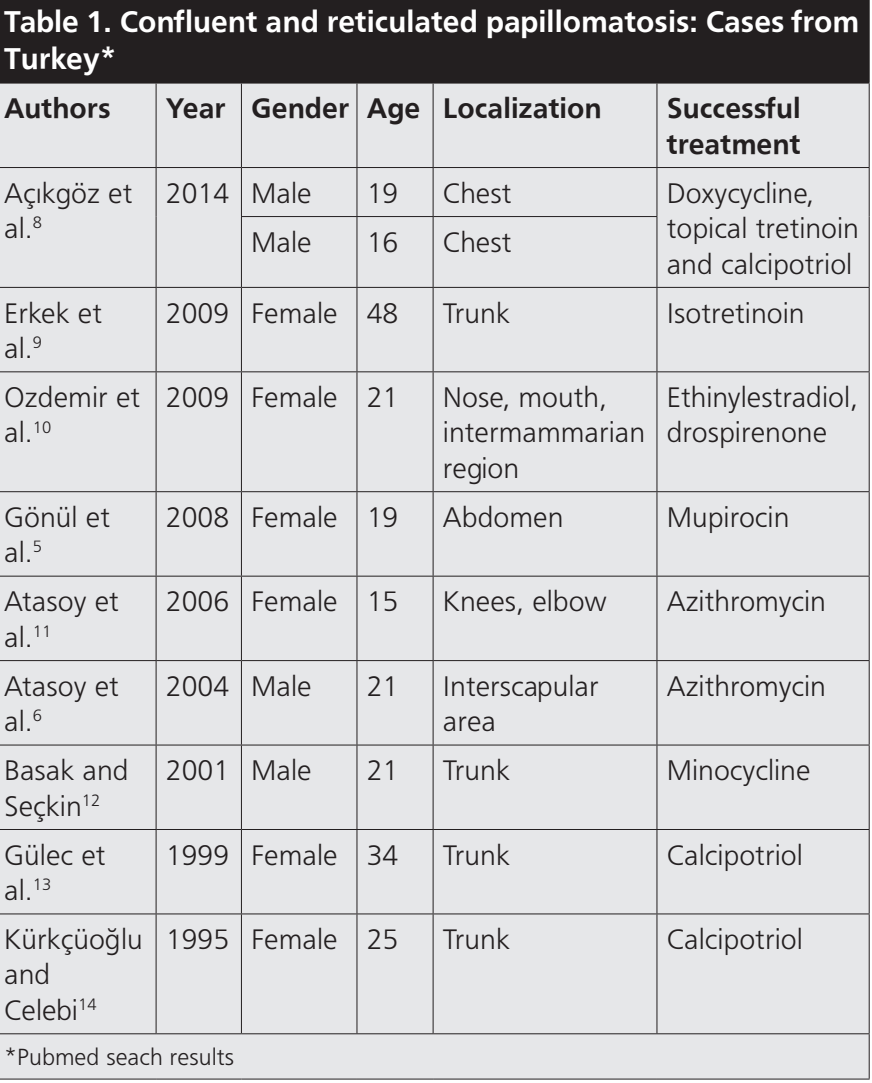

diagnosed by clinical and histopathological findings. Histopathological examination reveals mild hyperkeratosis, papillomatosis, focal acanthosis and superficial perivascular lymphocytic infiltration.

Although some treatment options such as salicylic acid, urea, topical and systemic retinoid, topical calcipotriol, tacrolimus, tazarotene, fluorouracil, antifungals, phototherapy and dermabrasion can be used, some studies of CRP performed in recent years have focused on the role of bacteria in the pathogenesis ${ }^{1,5-7}$. Good response to antibiotics such as minocycline and azithromycin in clinical practice reinforces this theory. Side effects of azithromycin are fewer than minocycline. In addition, macrolide and tetracycline groups have both antimicrobial and anti-inflammatory effects via inhibition of metalloproteinase, hydrolase, phospholipase A2, tumor necrosis factor alpha, interleukin (IL)-1 $\beta$, and IL- 6 as well as suppression of IL-8 and neutrophil oxidative burst $t^{1,3}$. Selenium sulphide can be effective due to keratolytic effect. Topical treatments such as tacrolimus are appropriate for relapsed patients with limited involvement. Systemic retinoids can be used in non-responders ${ }^{1}$. Therefore, antibiotics with anti-inflammatory effect are effective and a first-line treatment option in CRP. Thus, we selected tetracycline treatment with antimicrobial support of mupirocin which reduces epidermal proliferation by blocking of protein and DNA synthesis ${ }^{5}$. Complete remission was obtained in our patient after a 2-week oral tetracycline and topical mupirocin treatment.

Recurrence rates have been reported in the range of $13.8-15.4 \%$. In these patients, repeating of treatment with effective antibiotics in responders and administrating other treatment choices in nonresponders can be performed ${ }^{1}$. Our patient is doing well in the followup period of 36 months.

CRP is clinically similar to tinea versicolor and can be easily confused 
with some dermatological diseases. CRP should be kept in mind in patients with localized reticular pigmentation in the upper trunk and nape. Thus, unnecessary and ineffective treatments and time loss for patients can be prevented. Due to the side effects of some antibiotics, tetracycline and macrolide groups can be considered as a first-line treatment option.

\section{Ethics}

Informed Consent: Informed consent was taken from patient.

Peer-review: Externally peer-reviewed.

\section{Authorship Contributions}

Surgical and Medical Practices: H.A., H.Ö.K., M.G., Concept: H.A., H.Ö.K., M.G., Design: H.A., M.G., Data Collection or Processing: H.A., H.Ö.K., F.A.K., Analysis or Interpretation: H.A., M.G., Literature Search: H.A., M.G., Writing: H.A., H.Ö.K., M.G., F.A.K.

Conflict of Interest: The authors declare no conflict of interest.

Financial Support: The authors have no financial support.

\section{References}

1. Lim JH, Tey HL, Chong WS. Confluent and reticulated papillomatosis: diagnostic and treatment challenges. Clin Cosmet Investig Dermato 2016;9:217-23

2. Hamilton D, Tavafoghi V, Shafer JC, Hambrick GW, Jr. Confluent and reticulated papillomatosis of Gougerot and Carteaud. Its relation to other papillomatoses. J Am Acad Dermatol 1980;2:401-10.

3. Scheinfeld N. Confluent and reticulated papillomatosis: a review of the literature. Am J Clin Dermatol 2006;7:305-13.

4. Jang HS, Oh CK, Cha JH, Cho SH, Kwon KS. Six cases of confluent and reticulated papillomatosis alleviated by various antibiotics. I Am Acad
Dermatol 2001;44:652-5.

5. Gönül M, Cakmak SK, Soylu S, Kiliç A, Gül U, Ergül G: Successful treatment of confluent and reticulated papillomatosis with topical mupirocin. J Eur Acad Dermatol Venereol 2008;22:1140-2.

6. Atasoy M, Ozdemir S, Aktaş A, Aliağaoğlu C, Karakuzu A, Erdem T: Treatment of confluent and reticulated papillomatosis with azithromycin. J Dermatol 2004;31:682-6.

7. Davis MD, Weenig RH, Camilleri MJ: Confluent and reticulate papillomatosis (Gougerot-Carteaud syndrome): a minocycline-responsive dermatosis without evidence for yeast in pathogenesis. A study of 39 patients and a proposal of diagnostic criteria. Br J Dermatol 2006;154:287-93.

8. Açıkgöz G, Hüseynov S, Ozmen I, Oztürk Meral A, Gamsızkan M, Calışkan E: Confluent and reticulated papillomatosis (Gougerot-Carteaud syndrome) in two brothers. Acta Dermatovenerol Croat 2014;22:57-9.

9. Erkek E, Ayva S, Atasoy P, Emeksiz MC: Confluent and reticulated papillomatosis: favourable response to low-dose isotretinoin. J Eur Acad Dermatol Venereol 2009;23:1342-3.

10. Ozdemir S, Ozdemir M, Toy H: Confluent and reticulated papillomatosis associated with polycystic ovary syndrome treated with a combined contraceptive containing drospirenone. J Eur Acad Dermatol Venereol 2009;23:358-9.

11. Atasoy $M$, Aliağaoğlu C, Erdem T: A case of early onset confluent and reticulated papillomatosis with an unusual localization. J Dermatol 2006;33:273-7.

12. Basak PY, Baysal V, Ozcanli C: Confluent and reticulated papillomatosis: failure of response to calcipotriol and coincidental association with vascular mottling. J Eur Acad Dermatol Venereol 2001;15:591-2.

13. Gülec AT, Seçkin D. Confluent and reticulated papillomatosis: treatment with topical calcipotriol. Br J Dermatol 1999;141:1150-1.

14. Kürkçüoğlu N, Celebi CR. Confluent and reticulated papillomatosis: response to topical calcipotriol. Dermatology 1995;191:341-2. 